\title{
FACTORS AFFECTING PRODUCTION IN THEINTENSIFICATION OF LOWLAND RICE FARMING IN PARIGI MOUTONG REGENCY, INDONESIA
}

\author{
Sulaeman $^{1}$, Muhammad Basir Cyio ${ }^{1}$ and Rustam Abd Rauf ${ }^{1}$ \\ ${ }^{1}$ Faculty of Agriculture, Tadulako University, City of Palu, Indonesia \\ https://doi.org/10.35410/IJAEB.2020.5458
}

\begin{abstract}
The purpose of this study is to analyze the factors affecting production in the intensification of lowland rice farming. This research was conducted by descriptive analytical method. Population in this study were all farmers who cultivated paddy rice farming in two villages. Variable research is paddy rice production, land area (ha), amount of seeds used (kg), use of urea fertilizer $(\mathrm{kg})$, use of NPK fertilizer $(\mathrm{kg})$, use of $\mathrm{KCL}(\mathrm{kg})$, farmer's age (years old), farmer's education (year), labor, farmer's experience, frequency of agriculture counselling. The analysis model used was the Cobb-Douglass model of multiple regression analysis. Results of research are the effect of land area factor (X1), labor (X2), seed (X3), use of urea fertilizer (X4), use of NPK fertilizer (X5), use of KCL fertilizer (X6), frequency of agricultural counselling (X10) and intensification of farming (D) together (simultaneous) affect the intensification of rice farming to production (Yi) with $\mathrm{p}<0,05$. The coefficient of determination $(\mathrm{R} 2)=0.983$ or $98.30 \%$. Conclusion is the effect of production on the intensification of paddy rice farming where land area, labor, use of seeds, use of urea fertilizer, use of NPK fertilizer, use of $\mathrm{Kcl}$, frequency of counselling and the effect of farm intensification have significant effect. The effect of labor on intensification of paddy rice farming where production, experience, education and intensification of farming are significant.
\end{abstract}

Keywords: Production of paddy rice; Intensification of farming; Land area, Agricultural counselling

\section{INTRODUCTION}

Paddy rice farming is one of income and employment opportunities for rural communities, therefore it requires proper management by using effective and efficient production factors. Inefficient use of production factors in paddy rice farming will result in low production and high costs, and ultimately reduce farmers income. One of efforts to increase production is performed through intensification by improving rice cultivation technology. Utilization of available resources including land, water, plants and organism in rice farming has not been optimal(Peanparkdee and Iwamoto, 2019; Techarang et al., 2018)

In addition, rice is a staple food of more than $90 \%$ of Indonesia's population, rice farming provides employment and as a source of income for around 21 millions of agricultural households(Admin, 2017). Besides, rice is also a strategic political commodity, thus, domestic rice production is a benchmark for food availability of Indonesia (Mariyono, 2014). 
Food is a basic need that its fulfilment cannot be delayed and is crucial for the survival of a community. The main problem in realizing food security in Indonesia today is faster growth of food demand compared to the growth of its supply. The rapidly increasing demand is a result of an increase in population, economic growth, people's purchasing power and change of tastes. Meanwhile national food production capacity experience a slow growth and even stagnant due to competition in the use of land and water resources as well as stagnant growth of land and agricultural labor productivity(Santo and Moragues-Faus, 2019; Shukla et al., 2018)

As a staple food, rice will continue to have increasing market demand, in line with population growth. From the farmer's side, as long as there is enough water, Indonesian farmers can almost certainly grow rice. Because planting rice has become a part of life, besides because it is for family food security, also as a source of household income, therefore rice farming will continue to be carried out by farmers(Suharyanto and Indrasti, 2017).

For the fulfilment of adequate food in quantity and quality, both the central and regional governments continue to strive to encourage the rural agricultural sector as one of the main food providers through intensification and intensification of food crops. Efforts carried out include the provision of inputs, technology, water facilities, marketing of products and so on that make it possible to stimulate more optimal farming, so that finally there will be an increase in production and productivity(Chesney et al., 2019; Emerick, 2018)

Parigi Moutong Regency as one of rice producing regencies in Central Sulawesi Province has the following potential: (1) the availability of human resources as actors of rice farming, (2) land resources that are quite potential and allow for the development of rice plants, (3) availability of facilities and adequate infrastructure, (4) the application of good technology and (5) the accessibility of agricultural products from agricultural producing regions to other areas in Central Sulawesi Province.

Efforts to increase the productivity of paddy rice are expected to: $\mathrm{Be}$ able to guarantee the food availability and be able to meet the demand for rice consumption in the future, especially in Parigi Moutong Regency and generally in Central Sulawesi Province. The purpose of this study is to analyze the factors affecting production in the intensification of lowland rice farming

\section{METHOD}

\section{Research design}

This research was conducted by descriptive analytical method, namely a method in a research on the status of a group of humans, an object, a condition, a system of thought or a class of events in the present. Descriptive research aims to make a picture of the situation or event or provide an overview of the relationship between phenomena, test hypotheses, make predictions and the implications of a problems to solve.

ParigiMoutong Regency was selected as a research area based on some considerations that the location is one of the centers of rice production in Central Sulawesi Province and It is a development area for paddy rice commodities and is recommended for research due to its potentially good development. 


\section{Population and Sample}

Population in this study were all farmers who cultivated paddy rice farming in two villages.

Table 1 Number of research samples

\begin{tabular}{|llll|}
\hline No & Village & Total population & Total Sample \\
\hline 1 & Tolai barat & 198 & 66 \\
2 & Dolago Padang & 187 & 65 \\
\hline & Total & $\mathbf{3 8 5}$ & $\mathbf{1 3 1}$ \\
\hline
\end{tabular}

\section{Method of data collection}

Data collection used three kinds of techniques, including: (1) Observation, conducted by observing the object of research directly, (2) Interview, by asking for information through a list of questions that have been prepared in advance, and (3) Recording, namely data collection by recording existing data in the department or agency related to the research.

\section{Types and Source of Data}

Data collected in this research activity include primary data and secondary data: (1) Primary data was obtained through interviews with sample of the households using a list of prepared questions. Primary data is also obtained through interviews with related agencies. In addition, there were also field observations to see the object of research directly, and (2) Secondary data was obtained from available data in the relevant agencies, especially those related to policies to increase rice production and food security.

\section{DATA ANALYSIS}

Based on the objectives to be achieved from this study, the analysis model used was the Cobb-Douglass model of multiple regression analysis.

\subsection{Production Equation}

Answering the first objectives, for knowing and analyzing the effect of paddy rice farming intensification on production, a regression equation is used as follows :

$L n P r o d=\ln a_{0}+a_{1} \ln L H N+a_{2} \ln B N H+a_{3} \ln P U+a_{4} \ln P N P K+a_{5} \ln P K+$

$+a_{6} \ln U P+a_{7} \ln P P+a_{8} \ln P G+a_{9} \ln T K+a_{10} \ln F B+\delta_{1} \mathrm{D} 1+\varepsilon$

which :

PROD : paddy rice production

$\delta \quad:$ Dummy variable coefficient (estimated parameters) $(\mathrm{i}=1)$

a : intercept 
$\mathrm{a}_{\mathrm{i}} \quad$ : regression coefficient parameter yang ditaksir $(\mathrm{i}=1 \mathrm{~s} / \mathrm{d} 10)$

LHN : land area (ha)

$\mathrm{BNH} \quad$ : amount of seeds used $(\mathrm{kg})$

PU : use of urea fertilizer $(\mathrm{kg})$

PNPK : use of NPK fertilizer $(\mathrm{kg})$

PK : use of KCL $(\mathrm{kg})$

UP : farmer's age (years old)

PP : Farmer's Education (Yr)

TK : Labor (HOK)

PG : Farmer's Experience (Yr)

FB : frequency of agricultural counseling (how many times)

D1 : dummy variable of farming intensification

$\mathrm{D}=1$, if farmers cultivate their farming intensively

$\mathrm{D}=0$, if one of the farmers does not cultivate his farming intensively

$\varepsilon \quad$ : error term

\subsection{Equation on the Use of Chairperson}

Responding to the second objectives, to know and analyze the effect of paddy rice farming intensification on labor use, the regression equation is used as follows:

$\ln P T K=\ln b_{0}+b_{1} \ln P R O D+b_{2} \ln P P+b_{3} \mathrm{n} M P+\delta_{1} D 1+\varepsilon$

In which :

PTK : Labor use in rice farming (HOK)

$\delta \quad$ : Dummy variable coefficient (estimated parameters) $(i=1)$

b : intersept

bi : regression coefficient of estimated parameter ( $\mathrm{i}=1$ up to 3 )

PROD : rice production $(\mathrm{kg})$

PP : Farmer's Education (Yr) 
MP : farmer's work capital (Rp)

D1 : dummy variable of farming intensification

$\mathrm{D}=1$, if farmers cultivate their farming intensively

$\mathrm{D}=0$, if one of the farmers does not cultivate his farming intensively

$\varepsilon \quad$ : error term

\section{RESULTS AND DISCUSSION}

Regression Analysis of Factors Affecting Production in Intensification of paddy rice farming in Parigi Moutong Regency.

The effect of land area factor $\left(\mathrm{X}_{1}\right)$, labor $\left(\mathrm{X}_{2}\right)$, seed $\left(\mathrm{X}_{3}\right)$, use of urea fertilizer $\left(\mathrm{X}_{4}\right)$, use of NPK fertilizer $\left(X_{5}\right)$, use of KCL fertilizer $\left(X_{6}\right)$, age of farmer $\left(X_{7}\right)$, farmer's education $\left(X_{8}\right)$, Farmer's Experience $\left(\mathrm{X}_{9}\right)$, frequency of agricultural counseling $\left(\mathrm{X}_{10}\right)$ and intensification of farming (D) together (simultaneous) affect the intensification of rice farming to production $\left(\mathrm{Y}_{\mathrm{i}}\right)$ (Table 2)

Table2. Multiple Linear Regression Coefficients Between Independent Variables and Dependent Variables to Production Equations.

\begin{tabular}{|c|c|c|c|c|}
\hline No & Variable & $\begin{array}{l}\text { Regression } \\
\text { Coefficient }\end{array}$ & $t$-count & Sig. \\
\hline 1. & Constanta & 8,283 & 32,367 & 0,000 \\
\hline 2. & Land area $\left(\mathrm{X}_{1}\right)$ & 0,148 & 11,246 & 0,000 \\
\hline 3. & Labor $\left(\mathrm{X}_{2}\right)$ & 0,148 & 11,195 & 0,000 \\
\hline 4. & Seeds $\left(\mathrm{X}_{3}\right)$ & 0,140 & 17,130 & 0,000 \\
\hline 5. & Use of urea fertilizer $\left(\mathrm{X}_{4}\right)$ & 0,160 & 20,105 & 0,000 \\
\hline 6. & Use of NPK fertilizer( $\left.\mathrm{X}_{5}\right)$ & 0,219 & 24,985 & 0,000 \\
\hline 7. & Use of KCL fertilizer $\left(\mathrm{X}_{6}\right)$ & 0,199 & 23,047 & 0,000 \\
\hline 8. & Farmer's age $\left(\mathrm{X}_{7}\right)$ & $-0,060$ & $-0,677$ & 0,500 \\
\hline 9. & farmer's education $\left(\mathrm{X}_{8}\right)$ & 0,014 & 0,648 & 0,518 \\
\hline 10. & farmer's experience $\left(\mathrm{X}_{9}\right)$ & $-0,013$ & -0.670 & 0,504 \\
\hline 11. & $\begin{array}{l}\text { Frequency of agricultural counseling } \\
\left(\mathrm{X}_{10}\right)\end{array}$ & 0,151 & 16,135 & 0,000 \\
\hline
\end{tabular}




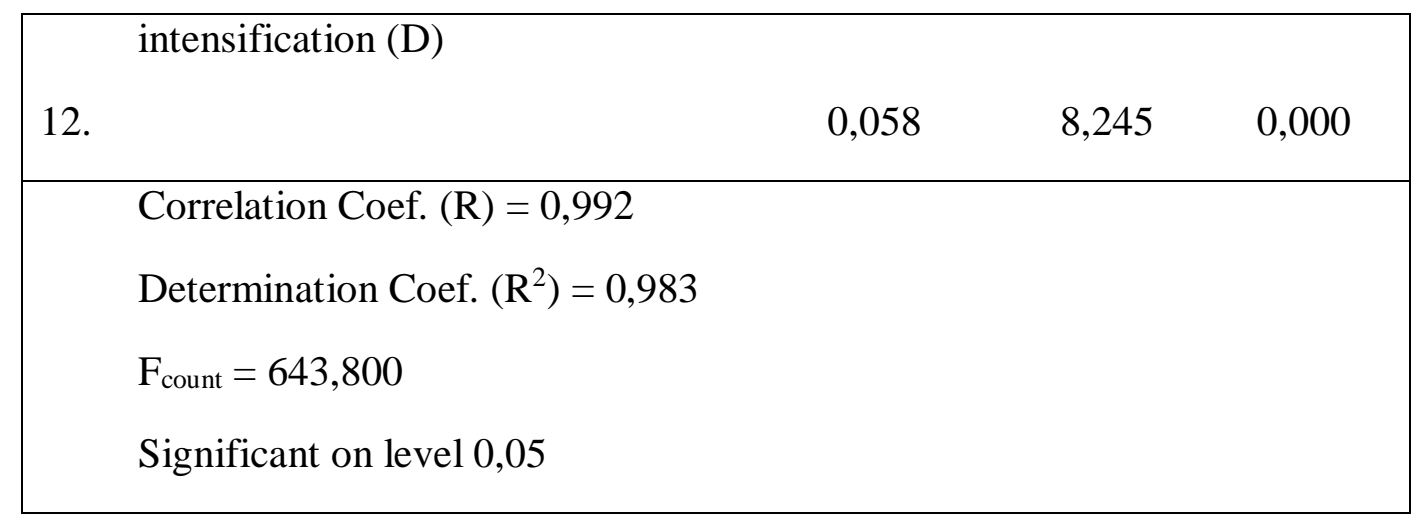

The results of the statistical tests can be written in the form of equations as follows :

$Y_{i}=8,283+0,148 X_{1}+0,148 X_{2}+0,140 X_{3}+0,160 X_{4}+0,219 X_{5}+0,199 X_{6}-0,060 X_{7}+$ $0,014 \mathrm{X}_{8}-0,013 \mathrm{X}_{9}+0,151 \mathrm{X}_{10}+0,058 \mathrm{D}$

Description :

$\mathrm{Y}_{\mathrm{i}}=$ paddy rice production

$\mathrm{X}_{1}=$ land $\operatorname{area}(\mathrm{Ha})$

$\mathrm{X}_{2}=$ Labor $(\mathrm{HOK})$

$\mathrm{X}_{3}=$ amount of seeds used $(\mathrm{Kg})$

$\mathrm{X}_{4}=$ Use of urea fertilizer $(\mathrm{Kg})$

$\mathrm{X}_{5}=$ use of NPK fertilizer $(\mathrm{Kg})$

$\mathrm{X}_{6}=$ use of $\mathrm{KCL}(\mathrm{Kg})$

$\mathrm{X}_{7}=$ Farmer's age $(\mathrm{Yr})$

$\mathrm{X}_{8}=$ farmer's education (Yr)

$\mathrm{X}_{9}=$ Farmer's Experience $(\mathrm{Yr})$

$\mathrm{X}_{10}=$ Frequency of agricultural counseling (How Many Times)

D1 =dummy variable of farming intensification

$\mathrm{a}_{0} \quad=$ Intersept

$a_{i}=$ regression coefficient $(i=1,2,3,4,5,6,7,8,9,10, D)$ 
Table 3 Analysis of F Test Variances on Production Equations.

\begin{tabular}{|lllllll|}
\hline No & $\begin{array}{l}\text { Source of } \\
\text { Variation }\end{array}$ & $\begin{array}{l}\text { sum of } \\
\text { squares }\end{array}$ & $\begin{array}{l}\text { Degree of } \\
\text { independence }\end{array}$ & $\begin{array}{l}\text { Average } \\
\text { squares }\end{array}$ & $\mathbf{F}_{\text {count }}$ & Significant \\
\hline 1 & Regression & 29,806 & 11 & 2,710 & 643,800 & $0,000^{\mathrm{b}}$ \\
\hline 2 & Remains & 0,501 & 119 & 0,004 & & \\
\hline 3 & Total & 30,307 & 130 & & & \\
\hline
\end{tabular}

Based on the results of analysis of variance or $\mathrm{F}$ test in table 3, it is known that $\mathrm{F}_{\text {count }}$ 643,800 is greater than $\mathrm{F}_{\text {table }}(11 ; 119)=1.86$. Thus it can be concluded that all independent variables, which consist of land area $\left(\mathrm{X}_{1}\right)$, labor $\left(\mathrm{X}_{2}\right)$, use of seeds $\left(\mathrm{X}_{3}\right)$, use of urea fertilizer $\left(\mathrm{X}_{4}\right)$, use of NPK fertilizer $\left(\mathrm{X}_{5}\right)$, use of $\mathrm{KCL}\left(\mathrm{X}_{6}\right)$, age of farmer $\left(\mathrm{X}_{7}\right)$, farmer's education $\left(\mathrm{X}_{8}\right)$, Farmer's Experience $\left(X_{9}\right)$, frequency of counseling $\left(X_{10}\right)$, dummy farming intensification variable (D1), simultaneously affect the paddy rice production $\left(\mathrm{Y}_{\mathrm{i}}\right)$ in $95 \%$ confidence level. These statements are understood that if the variable is added or reduced, it can increase or decrease the production of rice farming. The coefficient of determination $\left(\mathrm{R}^{2}\right)=0.983$ or $98.30 \%$ can be explained by the variable area of land, use of seeds, use of urea fertilizer, use of NPK fertilizer, use of KCL, age of farmers, farmer's education, labor, farmer's experience, frequency of counseling and intensification while the remaining $1.70 \%$ is another variable which is not included in the equation.

\section{Effect of Land Area $\left(\mathbf{X}_{1}\right)$ on the Farm Production.}

Positive sign of coefficient shows a positive relationship between land area and production of paddy rice farming. This implies that if the land area increases by 1 ha, the level of production of paddy rice will increase by $0.148 \%$ and vice versa if the land area decreases by 1 ha, the production of paddy rice will decrease by $0.148 \%$.

Land is a medium or place for growing plants and is an important factor in developing a farming. The wider the cultivated area the greater the production yielded. Likewise, on the contrary the narrower at area cultivated, the lower the production obtained. Te area of cultivated land is one of important factors in increasing farm production(Cintina and Pukite, 2018).

\section{Effect of Labor $\left(\mathbf{X}_{2}\right)$ On the Farm Production.}

A positive coefficient sign indicates a positive relationship between labor and production of paddy rice farming. This implies that if labor increases by $1 \mathrm{HOK}$, the level of production of paddy rice farming will increase by $0.148 \%$ and vice versa if the land area decreases by $1 \mathrm{HOK}$ then the production of paddy rice farming will decrease by $0.148 \%$.

Labor is an important element in managing paddy rice farming, because a large number of workers will assist activities in the production of paddy rice farming. According to respondents, the management of paddy rice production using labor still relies on the potential of existing labor in the family, this is due to lack of capital in terms of paying labor costs outside 
their families and with workers in their families can delay payment of fees if capital still not enough. The number of family members working on farm families is a source of labor for farming for farmers, therefore the more labor, the use of outside family labor decreases(Lowder et al., 2016).

\section{Use of seeds Effect $\left(\mathrm{X}_{3}\right)$ On the Farm Production.}

The positive coefficient sign shows a positive relationship between seed use and the production of paddy rice farming. This implies that if the use of seeds increases by $1 \mathrm{~kg}$, the level of production of paddy rice farming will increase by $0.140 \%$ and vice versa if the land area decreases by $1 \mathrm{~kg}$, the production of paddy rice farming will decrease by $0.140 \%$.

The use of quality seeds is the right solution to increase rice production. The case found in the field that farmers have been using the seeds for generations and have not used quality seeds, so that the production produced is very low. With the help of the Regional Government to provide superior seeds to farmers, the results show a better change in results. The use of superior seeds as one of the production inputs can increase production because it provides a positive influence on rice production. The obstacle to increase production that is felt so far is often a technical obstacle in the form of the application of production technology components that have not been utilized optimally such as the use of superior varieties(Saberi et al., 2010)

\section{Effect of Using Urea Fertilizers $\left(\mathrm{X}_{4}\right)$ on the Farm Production}

The positive sign of coefficient shows that there is a positive relationship between the use of urea fertilizer and the production of paddy rice farming. This implies that if the use of urea fertilizer increases by $1 \mathrm{~kg}$, the level of production of paddy rice farming will increase by $0.160 \%$ and vice versa if the use of urea fertilizer decreases by $1 \mathrm{~kg}$, the production of paddy rice farming will decrease by $0.160 \%$.

The use of urea fertilizer in research locations is still possible to use this to increase the yield of rice farming. The use of urea fertilizer indicates several things, namely (1) the level of land fertility has decreased, (2) the way of improper administration, (3) the timing of improper administration, and is possible because of the chemical properties of soil that can ensnare the element $\mathrm{N}$ so it is not available for plants. For this urea fertilizer to be sufficient for plants, farmers often provide urea fertilizer in large quantities, especially in the growth phase. The amount and proportion of nutrient loss is strongly influenced by the properties of the nutrient itself, are many lost due to evaporation(Amooh et al., 2015).

\section{Effect of Using NPK Fertilizers $\left(X_{5}\right)$ on the Farm Production}

The positive sign of coefficient shows that there is a positive relationship between the use of NPK fertilizer and the production of paddy rice farming. This implies that if the use of NPK fertilizer increases by $1 \mathrm{~kg}$, the level of production of paddy rice farming will increase by $0.219 \%$ and vice versa if the use of NPK fertilizer decreases by $1 \mathrm{~kg}$, the production of paddy rice farming will decrease by $0.219 \%$. 
NPK fertilizer is one of the fertilizers that are often used by farmers every time planting, NPK fertilizer is one type of fertilizer that is subsidized by the government so that the price is cheaper and affordable for farmers. Provision of NPK fertilizer is very good to accelerate growth and increase production. This fertilizer is widely used by paddy rice farmers, because it is able to increase crop yields and quality of grain sera to produce more full grains.

\section{Effect of Using $\mathrm{KCl}$ Fertilizers $\left(\mathbf{X}_{6}\right)$ on the Farm Production}

The positive coefficient sign shows a positive relationship between the use of $\mathrm{KCl}$ fertilizer and the production of paddy rice farming. This implies that if the use of $\mathrm{KCl}$ fertilizer increases by $1 \mathrm{~kg}$, the level of production of paddy rice farming will increase by $0.199 \%$ and vice versa if the use of $\mathrm{KCl}$ fertilizer decreases by $1 \mathrm{~kg}$, the production of paddy rice farming will decrease by $0.199 \%$.

Giving $\mathrm{KCl}$ fertilizer is also very related to the content of Potassium which has a role to strengthen the plant's body so that leaves, flowers and fruit are not easy. Potassium is a source of strength for plants in the face of drought and disease. With the condition of the growth and development of good and strong plants, it can automatically increase the production of paddy rice assuming other production factors are fulfilled.

\section{Effect of Farmer Age $\left(\mathrm{X}_{7}\right)$ on the Farm Production}

The negative coefficient sign indicates a negative relationship between the age of the farmer and the production of paddy rice farming. This implies that if the farmer's age increases by 1 year, the level of production of paddy rice farming will decrease by $-0.060 \%$ and vice versa if the age of the farmer decreases by 1 year, the production of paddy rice farming will increase by $-0.060 \%$.

From the results obtained, it can be concluded that the age of farmers in the research location is not an indicator of the ability to produce paddy rice farming, they rely more on their habits in terms of the technique of managing rice farming. Farmers in research locations only focus on how to get a lot of production and can be sold at adequate prices, besides farmers are more inclined to their own decisions based on existing habits and capital..

\section{Effect of farmer's education $\left(\mathbf{X}_{8}\right)$ on the Farm Production}

Positive sign of coefficient shows a positive relationship between land area and production of paddy rice farming. This implies that if farmer's education increases 1 year then the level of production of paddy farming will increase by $0.014 \%$ and vice versa if farmer's education decreases by 1 year then the production of paddy rice farming will decrease by $0.014 \%$.

Education has an important meaning because with adequate education farmers will be able to utilize and apply the cultivation techniques of rice farming to be able to increase production. Farmers who have received education are more open-minded and the horizons of thinking and education they have can direct farmers in making every rational decision. With 
education it can help farmers in the formation of a simple frame of mind that can be used to receive, process information and use that information in cultivating the farm.

Farmers who have low education, most of them only want the existence of sustainable farming, in the sense that the farmers only think about being able to produce, market and obtain price revenues from the sale of rice farming without considering the desire or opportunity to progress further.

\section{Effect of Farmer's Experience ( $\left.X_{9}\right)$ on the Farm Production}

The sign of a negative coefficient indicates a negative relationship between the experience of farmers and the production of paddy rice farming. This implies that if the farmer's experience increases by 1 year, the level of production of paddy rice farming will decrease by $0.023 \%$ and vice versa if the farmer's experience decreases by 1 year, the production of paddy rice will increase by $-0.023 \%$.

The more experience of farming that is owned by a farmer, the more effective the management of his farming, including selective in applying the cultivation techniques of rice field usatani in the field. The duration of farming experience is in line with the age of the farmers concerned, as long as the farmers are consistent with the type of farming. The size of this aspect of farming experience can be measured by the age of the farmer carrying out his farming. Basically the farming experience carried out by farmers in the research location is a long experience that they have done year after year. One of the habits that they have done so far is the use of superior seeds, especially in the varieties of superior seeds of paddy rice that they produce themselves which are on average from previous plants.

\section{Effect of Agricultural counseling Frequency $\left(X_{10}\right)$ on the Farm Production}

A positive coefficient sign indicates a positive relationship between the frequency of counseling and the production of rice farming. This implies that if the frequency of extension training increases 1 time, the level of production of paddy farming will increase by $0.151 \%$ and vice versa if the frequency of extension is decreased once, the production of paddy rice will decrease by $0.151 \%$.

From the description, it was concluded that the availability of extension and agricultural development institutions, especially rice farming in research locations is needed to increase insight and skills in farming. The main purpose of agricultural extension is to increase the ability of farmers in terms of behavior and skills in their farming. This means that through counseling it is expected that there will be changes in farmer behavior so that they can improve their farming methods and increase production. The task of agricultural counseling involves efforts to help farmers to constantly improve farm efficiency, while extension farmers are an educational opportunity outside of school where they can learn by doing.

According to the respondents' farmers at the research location, in general they can only take part in one or two scheduled coaching activities. Constraints faced by farmers in participating in counseling, among others, cannot share time well, so that it collides with other 
activities. Farmers are more likely to work on activities that can increase family income or be more preoccupied with family activities.

\section{Effect of Farm Intensification (D) on the Farm Production}

The positive coefficient sign shows a positive relationship between intensification of farming and the production of rice farming. This implies that if the intensification of farming increases 1 time, the level of production of paddy farming will increase by $0.058 \%$ and vice versa if the intensification of farming decreases once, the production of paddy rice farming will decrease by $0.058 \%$.

Paddy rice farming is classified as farming with high input costs, while promising a high profit value, it also has a high risk. For this reason, farmers who seek it will always consider any changes in costs that must be incurred as a result of technological changes. Farming intensification factors in research conducted with the use of innovation and technology adoption can encourage the gain of paddy farming production.

The process of adoption is a mental process that occurs in a person from the first time to recognize innovation until it adopts it. Adoption is defined as the full use of a new idea as the best way, then it is said that adopting an innovation or technology is a human decision, and the decision is based on four things, namely: (1) willingness to do something, (2) know how what to do, (3) know how to do it, and (4) own the tools to implement it.

The process of innovation is often equated with technology, technology is a design or pattern of action that is not direct (instrumental) which reduces the uncertainty of causal relationships that are seen in achieving the desired results. Every technology usually contains an idea component (software) and object components (hardware). The technology component of rice farming production is created due to the presence of ideas or ideas that enable the discovery of superior variatas, how to make natural fertilizers, and how to make certain pesticides that can kill or kill pests / diseases. Similarly, farming techniques require knowledge as a component of the idea.

Regression Analysis of Factors Affecting Labor in Intensification of paddy rice farming in Parigi Moutong Regency.

Multiple linear regression coefficients between independent variables and dependent variables can be seen in Table 4.

Table4 Multiple Linear Regression Coefficients Between Independent Variables and Dependent Variables to Labor Equations.

\begin{tabular}{|lllll|}
\hline No & Variable & $\begin{array}{l}\text { Regression } \\
\text { Coefficient }\end{array}$ & t-count & Sig. \\
\hline 1. & Constanta & 4,035 & 113,111 & 0,000 \\
2. & Production $\left(\mathrm{X}_{1}\right)$ & 0,229 & 6,229 & 0,000 \\
\hline
\end{tabular}




\begin{tabular}{|lllll|}
\hline 3. & farmer's experience $\left(\mathrm{X}_{2}\right)$ & 0,039 & 2,203 & 0,029 \\
4. & farmer's education $\left(\mathrm{X}_{3}\right)$ & 0,172 & 5,374 & 0,000 \\
5. & intensification (D) & 0,120 & 2,365 & 0,020
\end{tabular}

Correlation Coefficient $(\mathrm{R})=0,895$

Determination coefficient $\left(\mathrm{R}^{2}\right)=$ 0,800

$\mathrm{F}_{\text {count }}=126,163$

Significant on level 0,05

The results of the statistical tests can be written in the form of equations as follows :

$Y_{i}=4,035+0,229 X_{1}+0,039 X_{2}+0,172 X_{3}+0,120 D$

Description :

$\mathrm{Y}_{\mathrm{i}}=$ Labor

$\mathrm{X}_{1}=$ Production $(\mathrm{Kg})$

$\mathrm{X}_{2}=$ Farmer's Experience (Yr)

$\mathrm{X}_{3}=$ Farmer's Education (Yr)

D1 =dummy variable of farming intensification

$\mathrm{a}_{\mathrm{o}}=$ Intersept

$\mathrm{a}_{\mathrm{i}} \quad=$ regression coefficient $(\mathrm{i}=1,2,3, \mathrm{D})$

Analysis of variance $\mathrm{F}$ test is presented in Table 5 .

Table 5 Analysis of $F$ Test Variances on Labor Equations.

\begin{tabular}{|lllllll|}
\hline No & $\begin{array}{l}\text { Source of } \\
\text { variation }\end{array}$ & $\begin{array}{l}\text { Sum of } \\
\text { squares }\end{array}$ & $\begin{array}{l}\text { Degree of } \\
\text { independence }\end{array}$ & $\begin{array}{l}\text { Everage } \\
\text { squares }\end{array}$ & $\mathrm{F}_{\text {count }}$ & Significant \\
\hline 1 & Regression & 20,218 & 4 & 5,055 & 126,163 & $0,000^{\mathrm{b}}$ \\
\hline 2 & Remains & 5,048 & 126 & 0,040 & & \\
\hline 3 & Total & 25,266 & 130 & & & \\
\hline
\end{tabular}

Based on the results of analysis of variance or $\mathrm{F}$ test in table 4 , it is known that $\mathrm{F}_{\text {count }}$ 126.163 is greater than $\mathrm{F}_{\text {table }}(4 ; 126)=2.44$. Thus it can be concluded that all independent 
variables, consisting of production $\left(\mathrm{X}_{1}\right)$, farmer's experience $\left(\mathrm{X}_{2}\right)$, farmer's education $\left(\mathrm{X}_{3}\right)$ and dummy variable of farming intensification (D1) jointly (simultaneously) affect the workforce of paddy rice farming $\left(\mathrm{Y}_{\mathrm{i}}\right)$ at a 95\% confidence level. Understanding of these statements where if the variable is added or reduced, it can increase or decrease the workforce of rice farming. The coefficient of determination $\left(\mathrm{R}^{2}\right)=0.800$ or $80.00 \%$ can be explained by production variables, farmer's experience, farmer's education, and farm intensification while the remaining $20 \%$ is another variable which is not included in the equation.

\section{The Effect of Production $\left(\mathrm{X}_{1}\right)$ on Farming Workers.}

Positive sign of coefficient shows a positive relationship between production and labor of rice farming. This implies that if production increases by $1 \mathrm{~kg}$, the level of labor of paddy rice farming will increase by $0.229 \%$ and vice versa if production decreases by $1 \mathrm{~kg}$, the labor force of rice paddy farming will decrease by $0.229 \%$.

Employment opportunities describe the amount of availability of production businesses in employing the labor needed in the production process. Labor is an important element in managing paddy rice farming, because with a large number of workers who will assist activities in the application of rice paddy production technology. The utilization of labor in farming still relies on the potential of the energy that is in the family. Workers who only arise and develop from family sources are often unable to be optimally utilized, this results in the low productivity of the family workforce and subsequently often the results obtained do not meet the living needs of farmers and their families throughout the year.

\section{The Effect of Farmer's Experience $\left(\mathrm{X}_{2}\right)$ on Farming Workers}

The positive sign of coefficient shows that there is a positive relationship between the experience of farmers and laborers of paddy rice farming. This implies that if the farmer's experience increases by 1 year, the level of labor of paddy rice farming will increase by $0.039 \%$ and vice versa if the experience of the farmer decreases by 1 year then the labor force of rice paddy farming will decrease by $0.039 \%$.

The more experience of farming owned by a farmer, the more effective the management of his farm, including the more selective in applying technology in the field. The duration of farming experience is in line with the age of the farmers concerned, as long as the farmers are consistent with the type of farming. The size of this aspect of farming experience can be measured by the age of the farmer carrying out the farming on the commodity in question.

Farming experience is very closely related to the age level of a farmer(Tauer, 1995). Generally, the age of a farmer is always identical to his experience. Farming experience can influence success of a farming.

\section{The Effect of farmer's education $\left(\mathrm{X}_{3}\right)$ on Farming Workers.}

The positive sign of coefficient shows that there is a positive relationship between the education of farmers and the workforce of rice farming. This implies that if farmer's education increases 1 year then the level of labor of paddy rice farming will increase by $0.172 \%$ and vice 
versa if the experiences of farmer decreases by 1 year then the labor force of paddy rice farming will decrease by $0.172 \%$.

The relationship of education with work productivity is reflected in the level of income. Higher education results in high work productivity so that it also gets high income. Education and training can also be used as indicators of welfare levels. In the framework of developing human resources (farmers), tasks and challenges not only involve formal education but also training for those with low education.

\section{The Effect of Farm Intensification (D) on Farming Workers.}

The positive coefficient sign shows a positive relationship between intensification of farming and labor of paddy rice farming. This implies that if the intensification of farming increases 1 time, the level of paddy rice farming labor will increase by $0.120 \%$ and vice versa if the intensification of farming decreases 1 time, the rice farming labor will decrease by $0.120 \%$.

Labor is an important element in cultivating paddy rice farming, because a large number of workers will help activities in increasing productivity of paddy rice farming. According to respondent farmers, the management of paddy rice cultivation still relies on the potential of existing labor in the family, this is caused by a lack of work capital for paying labor costs. By hiring workers from their own families, they can delay the payments when sufficient capital is not available.

\section{CONCLUSION}

On the effect of production on the intensification of paddy rice farming where land area, labor, use of seeds, use of urea fertilizer, use of NPK fertilizer, use of Kcl, frequency of counseling and the effect of farm intensification have significant effect, while farmer's age, education and experience have no real effect.On the effect of labor on intensification of paddy rice farming where production, experience, education and intensification of farming are significant.

Suitable policies from the Regional Government is necessary to ensure increased production of grain and ricefrom farmers in terms of availability of alsintan, good irrigation systems, superior varieties of seeds, guaranteed grain price, information on agricultural technology, and work capital for farmers. The paddy rice farmers in Parigi Moutong Regency are expected to have an efficient allocation for labor in carrying out their farming.

\section{REFERENCES}

Admin, 2017.Beras di Indonesia - Produksi\&Konsumsi [WWW Document]. URL https://www.indonesia-investments.com/id/bisnis/komoditas/beras/item183 (accessed 9.20.19).

Amooh, Maurice, Mensah, 2015. Effects of Soil Texture and Organic Matter on Evaporative Loss of Soil Moisture. Journal of Global Agriculture and Ecology 3, 152-161. 
Vol. 5, No. 01; 2020

ISSN: $2456-8643$

Chesney, T., Evans, K., Gold, S., Trautrims, A., 2019. Understanding labour exploitation in the Spanish agricultural sector using an agent based approach. Journal of Cleaner Production 214, 696-704. https://doi.org/10.1016/j.jclepro.2018.12.282

Cintina, V., Pukite, V., 2018. Analysis of influencing factors of use of agricultural land. Research for Rural Development, Latvia, pp. 181-187. https://doi.org/10.22616/rrd.24.2018.028

Emerick, K., 2018. Agricultural productivity and the sectoral reallocation of labor in rural India. Journal of Development Economics 135, 488-503. https://doi.org/10.1016/j.jdeveco.2018.08.013

Lowder, S.K., Skoet, J., Raney, T., 2016. The Number, Size, and Distribution of Farms, Smallholder Farms, and Family Farms Worldwide. World Development 87, 16-29. https://doi.org/10.1016/j.worlddev.2015.10.041

Mariyono, J., 2014. Rice production in Indonesia: policy and performance. Asia Pacific Journal of Public Administration 36, 123-134. https://doi.org/10.1080/23276665.2014.911489

Peanparkdee, M., Iwamoto, S., 2019. Bioactive compounds from by-products of rice cultivation and rice processing: Extraction and application in the food and pharmaceutical industries. Trends in Food Science \& Technology 86, 109-117. https://doi.org/10.1016/j.tifs.2019.02.041

Saberi, S., Mohd.Yusu, R., Zulkifli, N., MegatAhma, M.M.H., 2010. Effective Factors on Advanced Manufacturing Technology Implementation Performance: A Review. Journal of Applied Sciences 10, 1229-1242. https://doi.org/10.3923/jas.2010.1229.1242

Santo, R., Moragues-Faus, A., 2019. Towards a trans-local food governance: Exploring the transformative capacity of food policy assemblages in the US and UK. Geoforum 98, 7587. https://doi.org/10.1016/j.geoforum.2018.10.002

Shukla, S., Singh, S.P., Shankar, R., 2018. Evaluating elements of national food control system: Indian context. Food Control 90, 121-130. https://doi.org/10.1016/j.foodcont.2018.02.046

Suharyanto, S., Indrasti, R., 2017. Assessment of Food Security Determinants Among Rice Farming Households in Bali Province. KnE Life Sciences 2, 658. https://doi.org/10.18502/kls.v2i6.1088

Tauer, L., 1995.Age and Farmer Productivity. Review of Agricultural Economics 17, 63-69. https://doi.org/10.2307/1349655

Techarang, J., Yu, L.D., Tippawan, U., Phanchaisri, B., 2018. Ion beam genetic-technology for modification of rice phenotypes. Surface and Coatings Technology 355, 207-214. https://doi.org/10.1016/j.surfcoat.2018.02.103 